\title{
HYDROGEOLOGICAL SECTIONS OF THE PERGAMINO BASIN (BUENOS AIRES PROVINCE, ARGENTINA): AUDIO MAGNETOTELLURIC AND GEOCHEMICAL RESULTS.
}

\author{
C. Sainato ${ }^{1}$, M. C. Pomposiello ${ }^{2}$, A. Landini ${ }^{3}$, G. Galindo ${ }^{3}$ \& H. Malleville ${ }^{1}$ \\ Received March 23, 2000 / Accepted January 22, 2001
}

\begin{abstract}
Aquifers in the northeastern zone of the Buenos Aires Province, mainly used for agricultural purposes, were studied regionally by several authors, but local studies are necessary because great variations may occur in different basins, and well data are limited. In this work, geophysical exploration by means of Audio-magnetotelluric soundings and geochemical analyses of some well data were carried out at the Pergamino rivulet basin. Depth and thicknesses of the upper hydrogeological section, the Epiparaniana, including the Pampeano and Puelches aquifers, were determined. Also, the hydro chemical evolution along the direction of regional groundwater flow was studied. The depth of the very conductive layer corresponding to the salty Puelches and the "Green Miocene", limiting the agricultural water usage, came out to be very variable depending on the zone. Geochemical analyses showed that the Pampeano aquifer has bicarbonate sodium water, with an increase of electrical conductivity, sodium and bicarbonates contents at a local recharge zone with impermeable and bad drainage soils and a topographical small slope.
\end{abstract}

Key words: Audio-magnetotellurics; Aquifers; Hydrochemistry; Pergamino basin.

\begin{abstract}
SEÇÕES HIDROGEOLÓGICAS DA BACÍA DE PERGAMINO (PROVÍNCIA DE BUENOS AIRES, ARGENTINA): RESULTADOS AUDIOMAGNETOTELÚRICOS E GEOQUÍMICOS - Vários autores têm estudado regionalmente os aqüiferos na zona nordeste da provincia de Buenos Aires, principalmente aqueles usados na agricultura, mas, como os dados de poços são limitados, torna-se necessário efetuar pesquisas locais já que há grandes variações segundo as diferentes bacías. Neste trabalho, realizaram-se explorações geofísicas (audio-magnetotelúricas) e análises geoquímicas na bacía de Pergamino. Pesquisou-se também a evolução hidroquímica na direção do fluxo regional da água no solo. Determinaram-se a profundidade e espessura da seção superior hidrológica, a Epiparaniana, incluindo os aqüiferos Pampeanos e Puelches. A profundidade do estrato condutivo correspondente aos Puelches salgados e o "Green Miocene", que limitam o uso da água na agricultura, resultou muito variável segundo a zona. As análises geoquímicas mostraram que a água Pampeana é bicarbonatada sódica com um incremento na condutividade, com conteúdo de sódio e bicarbonatos na zona de recarga local, que tem solos impermeáveis, má drenagem e um leve declive.
\end{abstract}

Palavras-chave: Audio-magnetotelúrica; Aqüifero; Hidroquímica; Bacía de Pergamino.

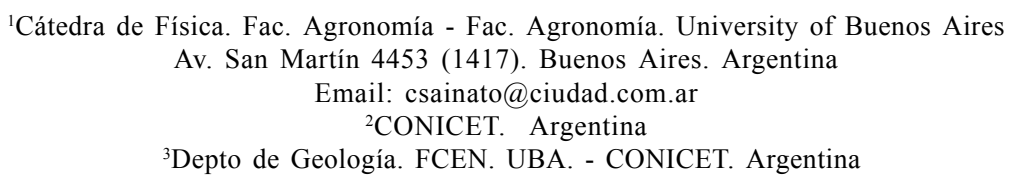




\section{INTRODUCTION}

The aquifers of the Northeastern zone of the Buenos Aires (Bs. As.) Province have been studied at a regional scale by some authors (Santa Cruz \& Silva Busso, 1995; Sala \& Rojo, 1994; Usunoff, 1994) but there is not enough knowledge of groundwater resources at the local scale, being hydrogeological and geophysical data limited and sparse. The hydrogeology of the Bs. As. Province is very difficult because of the flat terrain and lack of outcrops. Therefore, analysis of the profiles requires the interpolation of information from sites located at great distances from each other.

Santa Cruz \& Silva Busso (1995) have made a regional description of the two most important hydrogeological units: the Pampeano and Puelches aquifers, determining thicknesses between 45 and 125 $\mathrm{m}$ for the first one and a top at 50-100 $\mathrm{m}$ for the Puelches aquifer. In most sites Vertical Electrical Soundings (VES) have revealed a conductive layer with very low resistivities at almost $100 \mathrm{~m}$ depth which was associated with aquifers with highly saline water (Puelches Formation).

In order to increase the knowledge of the hydrogeology of the north-eastern part of the Buenos Aires Province, some geophysical studies have been carried out at local scale beginning with the PergaminoArrecifes river basin. Sainato et al. $(1998 ; 2000)$ carried out seventeen VES, that resulted in the description of the features of the Pampeano aquifer which include free groundwater and deeper semiconfined aquifers. A study of free groundwater water quality using geophysical and well data was done. Free groundwater level was found at 5-7 m depth and at some places it was almost superficial. These results have shown that the Pampeano aquifer is located beneath the free
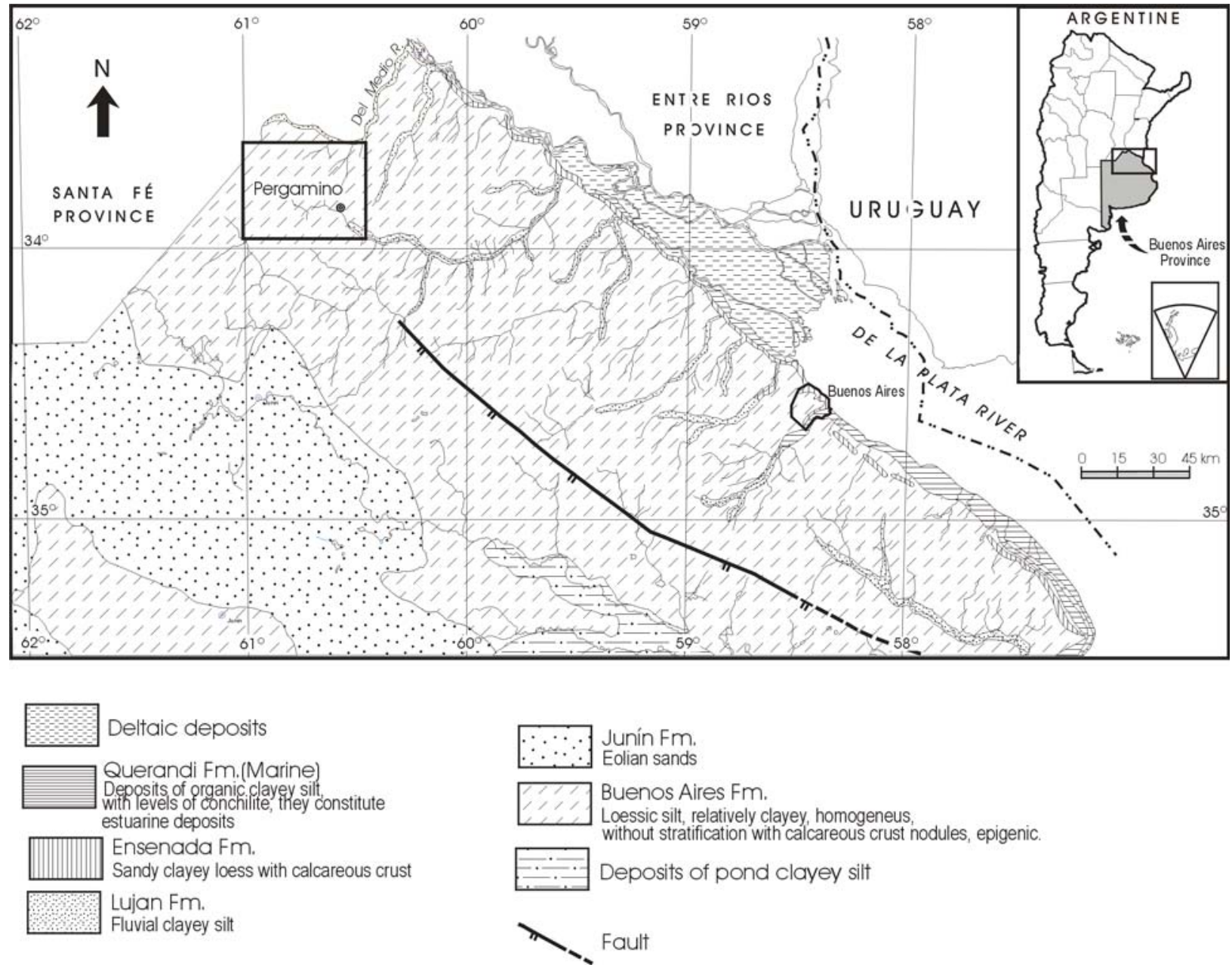

Figure 1 - Geological map of the northern part of Bs. As. Province. Argentina Location of study zone. From Secretaría de Industria, Comercio y Minería. Gobierno de la Pcia. De Bs. As. Argentina.

Figura 1 - Mapa geológico da parte norte da Pcia de Bs. Ás. Argentina.Locação da área de estudo. Da Secretaría de Industria, Comercio y Minería. Gobierno de la Pcia. De Bs. As. Argentina. 
groundwater level and the observed changes in electrical resistivity are influenced by lithology and water quality. Its multilayer behaviour with intercalation of sand and clayey sediments (semiconfined aquifer) reflected average resistivities between 6 and $21 \mathrm{ohm}$ $\mathrm{m}$. The limit between fresh-salt water was then determined by the top of the high conductive layer and some resistive intercalated layers were determined at some sites whose thicknesses were doubtful because of the absence of sufficient well data.

The scope of this work was to have a better description of this resistive layer and of the very high conductive one, trying to obtain deeper information, using Audio-Magnetotelluric Soundings (AMT). It is important to determine the thicknesses of the aquifers that have good quality water which constitute a limitation in the available water for irrigation. Then, it was necessary to define more precisely the limit between good quality and salty water and to have a better description of groundwater resources at the basin, as well as to evaluate their chemical properties.

The studied zone is placed within the Rosario basin limited by faults in a NW-SE direction (Irigoyen, 1975) at the NW of the Pergamino city (NE of Bs. As. Province, Argentina), along the basin of the river named alike (Fig. 1, Fig. 2) . The main physiographic environment is the Pampean plain, characterized by dissection troughs and terraces. The soft topographic slopes increase infiltration and/or evapotranspiration which hinder the superficial running off (Sala, 1975).

Twelve Audio-magnetotelluric soundings were carried out and water samples were taken at the available wells for chemical analyses .

\section{GEOLOGICAL AND HYDROGEOLOGICAL SETTING}

In Fig. 1 a geological map with the outcroppings sediments may be observed. As it has been pointed out there are very few wells in the area and no geological cross-section within the study zone is available. At the Rosario basin, where the Pergamino zone is placed (Fig. 2), Irigoyen (1975) recognized the main stratigraphic sequences found at the Salado basin, although the last one is deeper and has greater dimensions.

At the Rosario basin the sedimentary sequence is placed over basalts equivalent to those of Serra Geral found at the Argentine Mesopotamia. The top of this Formation is deeper at our study zone, reaching approximately $800 \mathrm{~m}$ depth (Fernández Garrasino \& Urba, 1999).

Three main hydrogeological units are recognized at the Pergamino zone, the so called the Northern environment: the Hipoparaniana, the Paraniana and the



Figure 2 - Structural map and Sedimentary basins . From Urien \& Zambrano (1996).

Figura 2 - Mapa estruturale. Bacias sedimentares da Pcia. De Bs. Ás. De Urien \& Zambrano (1996). 
Epiparaniana. The main features of these units are described bellow, following Sala (1969) and Sala et al. (1983), among others.

\section{Hipoparaniana section}

These Tertiary sediments are placed above the impermeable basement. The upper part of this section is called the "Red Miocene". It is formed by sandstones and red clays with an intercalation of ash and gypsum (Red Miocene) of continental origin with a thickness of up to $250 \mathrm{~m}$ and its top at $400-500 \mathrm{~m}$ depth, deepening to the southwest. The recharge comes from the NW, and in some cases a vertical contribution is also added. The discharge is mainly at the littoral (Paraná river basin). The water is generally salty, except in the south of the Bs. As. Province, where it is an artesian aquifer with better quality of water.

\section{Paraniana section}

The Paraniana section is formed by marine sediments called "Green Miocene" (Upper Miocene). It is formed by grey - blue and green clays with an intercalation of sand (Paraná Formation or Green
Miocene). Its thickness varies between 75 and $135 \mathrm{~m}$.

At the west and northwest of the Bs. As. Province, there is some intercalation of gypsum. The clay sediments that formed the top cover sandy layers increase their thickness towards the southeast (Salado river basin). This section has very saline water, in general.

The water lodged in the aquifers of the Paraniana section presents saline values of 10 to $30 \mathrm{~g} / 1$ (approximate conductivities of 16666 to $50000 \mathrm{mS} / \mathrm{cm}$ ).

\section{Epiparaniana section}

This section is located over the "Green Miocene" with horizontal and vertical flows being the recharge or discharge path of the deeper aquifers. It is formed by the Puelches Formation (Upper TertiaryQuaternary) and the sediments of the Pampeano (Quaternary) and the Post- Pampeano.

The Puelches sands constitute a semiconfined aquifer. They are quartziferous yellowish sands, of medium grain, with intercalation of gravel at greater depths and silt contents at shorter depths. Santa Cruz \& Silva Busso (1995) reported a thickness which varies from 10 to $25 \mathrm{~m}$ and the top is between 50 and $100 \mathrm{~m}$

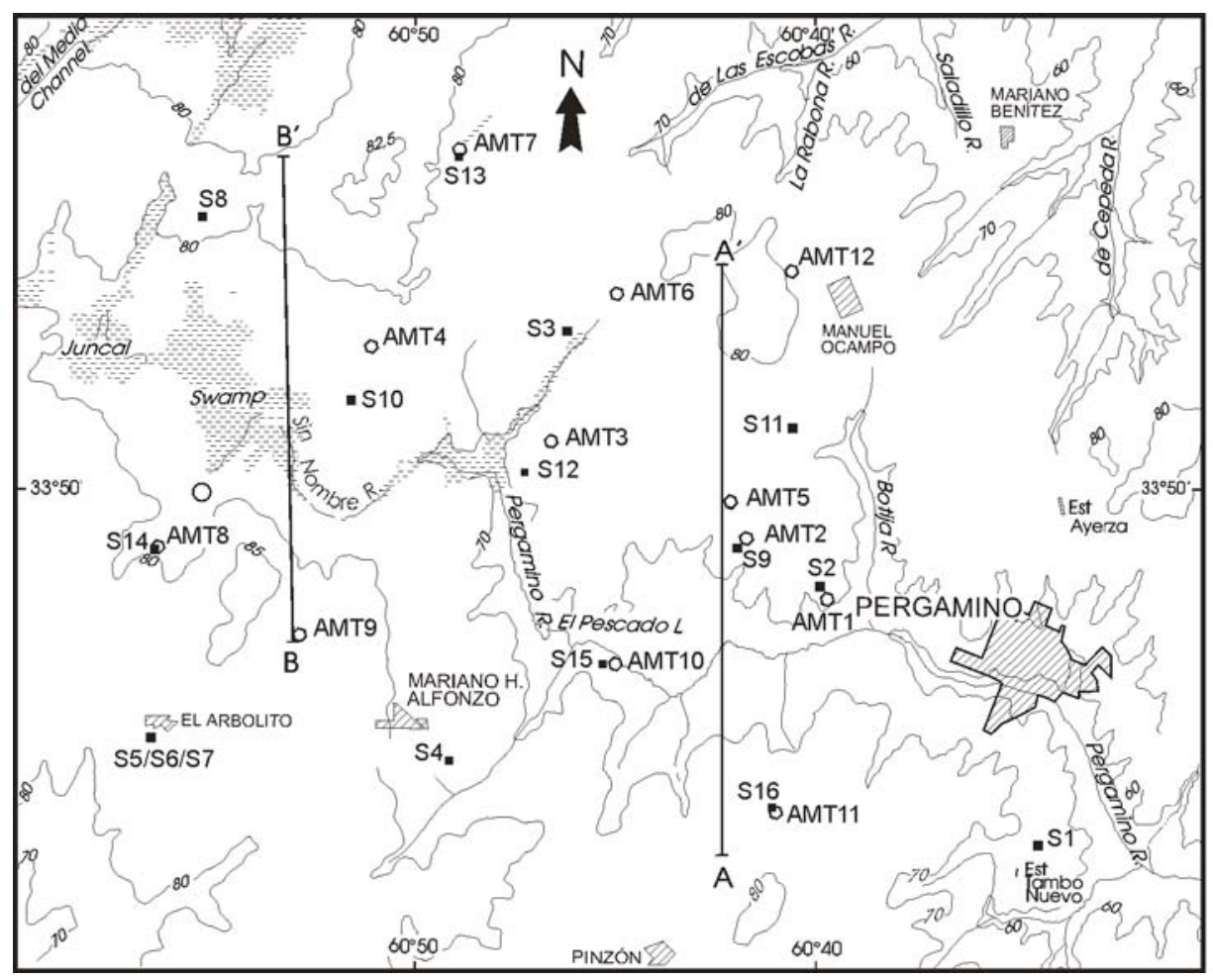

PERGAMINO ZONE

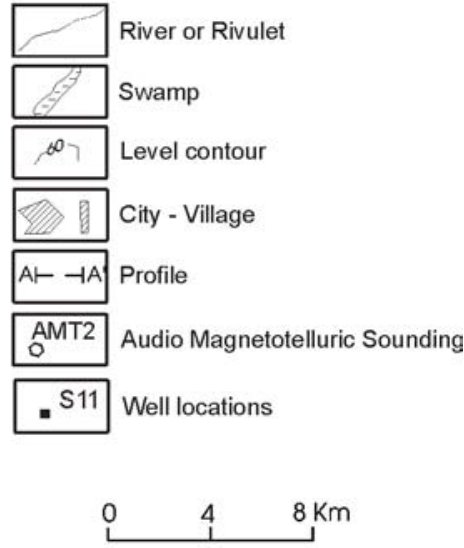

Figure 3 - Study area. Sites of AMT soundings and well locations are shown. Profiles for AMT interpretation are plotted on a topographic map.

Figura3 - Área de estudo e locação das sondagens AMT e dos poços. Os perfis são indicados para a interpretação dos resultados AMT no mapa topográfico. 


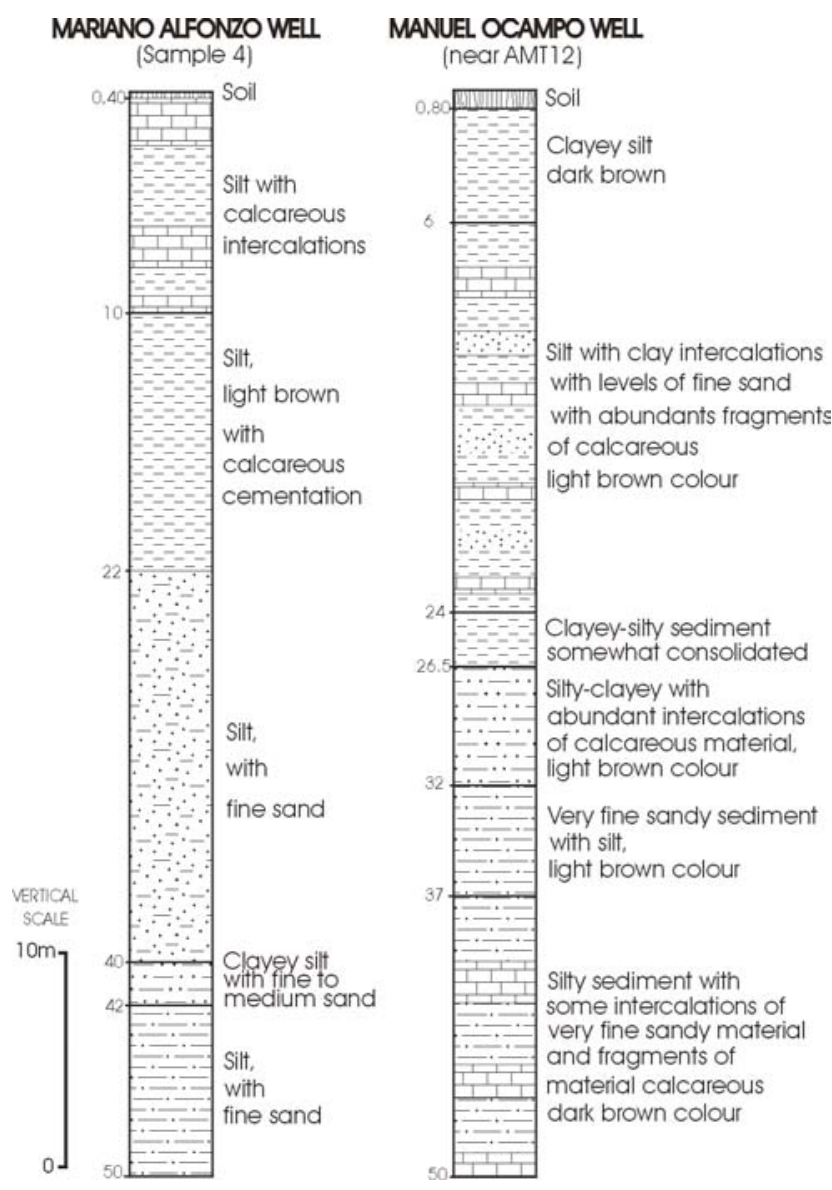

Figure 4 - Lithological description of two wells at towns M. Alfonzo and M. Ocampo.

Figura 4 - Perfil litológico de dois poços nas cidades de $M$. Alfonzo e M. Ocampo. depth approximately. The Pampeano whose thickness may vary between 20 and $120 \mathrm{~m}$ (Santa Cruz \& Silva Busso, 1995) contains the phreatic or free aquifer and some deeper semiconfined aquifers. The Pampeano aquifer has a sequence of permeable (with greater contents of sand) and impermeable (more clayey) horizontally layered levels, which constitutes a multiple or multiunitary aquifer. It has particles in suspension with fractions of sand and clay. There are also calcareous nodules or continuous layers, which have good permeability, formed by agglomerates with spherical shapes. In general, the direction of the regional phreatic runoff at the northern part of Bs.As. Province is from W-NW to E-SE, with local variations at the different hydrogeological basins. There is an autochthonous recharge (by means of precipitation), and indirect recharge by vertical infiltration (upward flow) added to the regional horizontal component (Santa Cruz \& Silva Busso, 1995).

Water quality of the Puelches aquifer is worse towards the west of the northern Bs.As. Province (Santa Cruz \& Silva Busso, 1995), where values of saline residual are greater than $2 \mathrm{~g} / \mathrm{l}$. To the east, better quality conditions show values lower than $500 \mathrm{mg} / \mathrm{l}$. Salinity grade varies with the zone (recharge and discharge areas). In general, it is related to bicarbonate sodium water.

The Pampeano aquifer also shows an increase in water salinity towards the west of the area, being the dry residue $800 \mathrm{mg} / \mathrm{l}$ in Arrecifes and $1000 \mathrm{mg} / \mathrm{l}$ at

\begin{tabular}{|c|c|c|c|c|c|c|c|c|c|c|}
\hline Sample & Conductivity & $\mathrm{pH}$ & chlorides & sulphates & carbonates & bicarbonate & sodium & potassium & calcium & magnesium \\
\hline & $\mu S . / \mathrm{cm}$ & & megil & meg/l & megil & megil & meq/l & megil & megil & megil \\
\hline 51 & 1052 & 8,77 & 0,79 & 1,20 & 1,09 & 7,97 & 9,70 & 0,38 & 0,45 & 0,50 \\
\hline 52 & 961 & 9,33 & 0,66 & 0,40 & 1,09 & 8,42 & 9,70 & 0,38 & 0,70 & 0,42 \\
\hline 83 & 3730 & 9,09 & 17,88 & 8,00 & 1,81 & 9,06 & 27,16 & 1,52 & 2,70 & 4,00 \\
\hline 84 & 1412 & 8,42 & 2,89 & 2,50 & - & 9,92 & 13,58 & 0,45 & 0,45 & 0,42 \\
\hline 55 & 1261 & 9,13 & 0,54 & 0,20 & 1,09 & 11,64 & 12,94 & 0,43 & 0,35 & 0,50 \\
\hline 86 & 2110 & 9,27 & 3,93 & 4,00 & 2,72 & 11,10 & 20,05 & 0,74 & 0,65 & 1,44 \\
\hline 87 & 2100 & 9,01 & 3,67 & .4 .80 & 0,91 & 12,46 & 18,11 & 0,68 & 0,70 & 1,60 \\
\hline 58 & 1565 & 9,05 & 1,97 & 0,83 & 0,91 & 11,37 & 13,35 & 0,77 & 0,75 & 0,60 \\
\hline 89 & 1500 & 7,27 & 1,44 & 2,38 & - & 12,56 & 12,53 & 0,48 & 1,05 & 1,25 \\
\hline 810 & 5900 & 6,37 & 26,21 & 19,86 & - & 15,21 & 54,83 & 1,90 & 2,5 & 2,33 \\
\hline 811 & 1500 & 7,04 & 1,69 & 2,59 & - & 11,74 & 12,66 & 0,56 & 0,95 & 1,25 \\
\hline 812 & 2800 & 7,65 & 7,33 & 8,03 & - & 14,11 & 29,37 & 0,58 & 0,95 & 0,83 \\
\hline 513 & 2200 & 8,10 & 4,71 & 1,39 & 2,81 & 11,72 & 16,83 & 0,84 & 0,6 & 0,93 \\
\hline 814 & 2300 & 8,40 & 4,19 & 3,10 & 3,03 & 12,12 & 19,27 & 0,59 & 0,6 & 0,83 \\
\hline 515 & 1800 & 8,20 & 2,80 & 3,10 & 2,48 & 10,15 & 14,98 & 0,50 & 0,9 & 1,50 \\
\hline 516 & 1000 & 7,80 & 0,59 & 1,99 & 0,62 & 7,78 & 8,21 & 0,60 & 0,68 & 0,76 \\
\hline
\end{tabular}

Table 1 - Hydrochemical analysis. Sample locations are shown in Fig. 3.

Tabela 1 - Análise hidroquimica. A locação das amostras é mostrada na Fig. 3. 

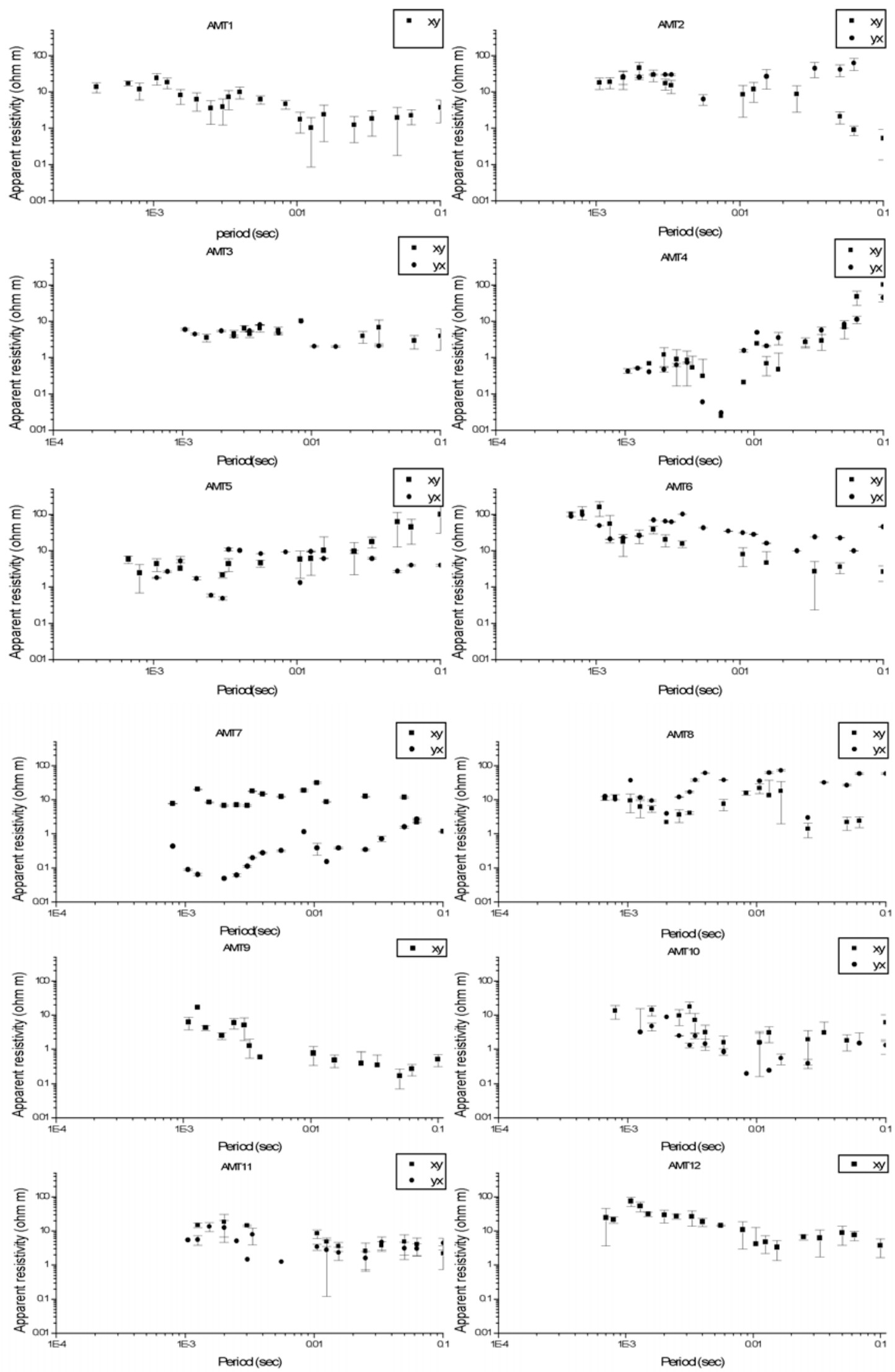

Figure 5 - Apparent resistivity curves as a function of period corrected by static shift and Rhoplus code for each AMT site.

Figura 5 - Curvas de resistividade aparente em função do periodo corrígidas para efeito estáticos e o programa Rhoplus. 

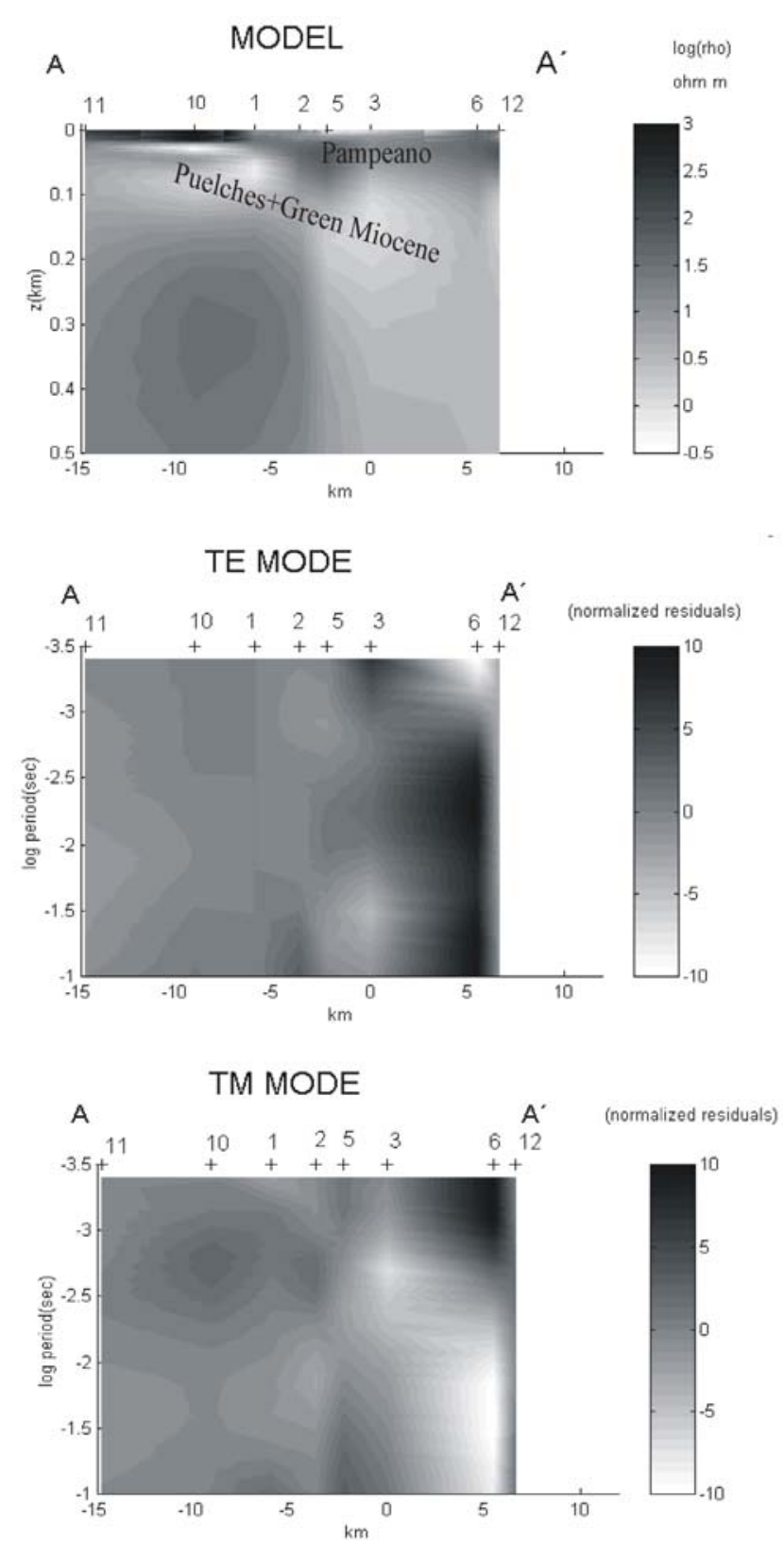

Figure 6a - AMT Profile AA'. Model and normalized residuals after RRI inversion of TE and TM modes.

Figura 6a - Perfil AA'. Modelo e resíduos normalizados depois da inversão dos modos TE e TM.

Pergamino. Free groundwater and water of the semiconfined Pampeano are of bicarbonate sodium type. Salinity of the this section increases at the flood plains of the rivers and rivulets and towards their beds (discharge zones) with values of conductivity s greater than $1000 \mathrm{mS} / \mathrm{cm}$ at the $\mathrm{N}$ and $\mathrm{S}$ of Pergamino city.

Values of Sodium absorption rate (SAR) between 10 and 13 were registered in the zone. From the irrigation point of view, the Puelches and Pampeano aquifers show in general, similar features with water classified as $\mathrm{C}_{3} \mathrm{~S}_{2}$ (moderate risk of sodium and high


Figure. 6 b - AMT Profile BB'. Model and normalized residuals after RRI inversion of TM mode.

Figura $6 \boldsymbol{b}$ - Perfil BB'. Modelo e resíduos normalizados depois da inversão do modo TM.

of salinity) and $\mathrm{C}_{3} \mathrm{~S}_{3}$ (high risk of sodium and salinity) (Sainato et al., 1998; 2000).

\section{PREVIOUS GEOPHYSICAL RESULTS}

Seventeen VES were performed at the studied zone by Sainato et al. (1998; 2000), at the same sites where this work was carried out. The models of the resistivity distribution obtained enable to determine the depth of the free aquifer, which is the hydraulic potentiometric level. Isolines of these levels were constructed allowing to know the direction of hydraulic gradient. These results have shown that free groundwater flow has a recharge coinciding with topographic high zones whereas the discharge is mainly towards the Pergamino river. As a result of the electrical resistivities of free groundwater obtained from the soundings at the different sites, water conductivity has been found greater at the bed of the river. This may be a consequence of being a discharge area, a 

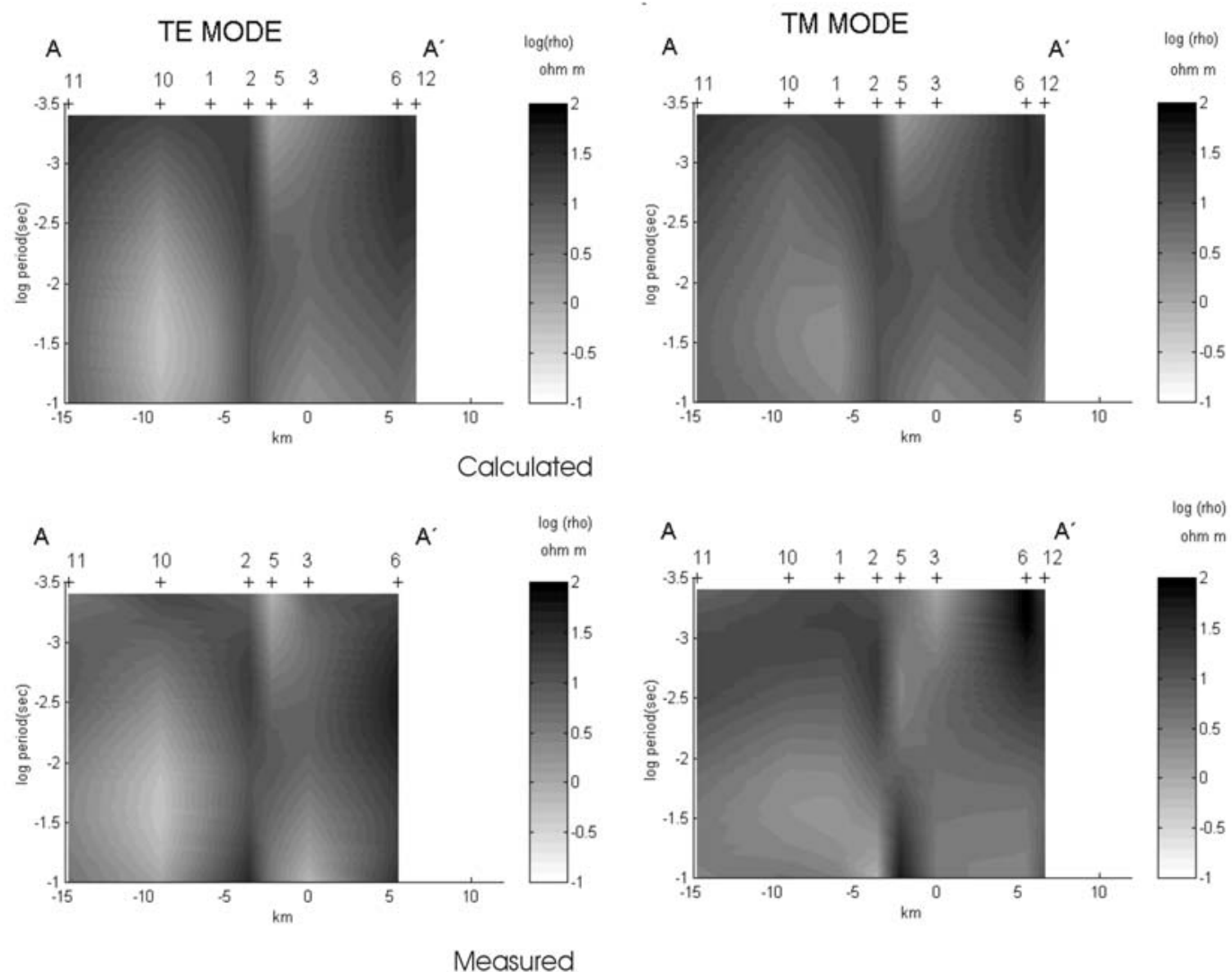

Figure 7 - Calculated and measured pseudosections of apparent resistivity for TE and TM modes for profile AA'.

Figura 7 - Pseudo-seções de resistividade aparente calculada e medida para o modo TE e TM para o perfil AA'.

small slope of hydraulic gradient, and Natracuolls soils with very small grain size, all of which increases time of residence of water and dissolution of salts. The deeper aquifers of the multilayer Pampeano and even the Puelches have revealed lateral discontinuities in electrical resistivities which were associated with structural controls based on Irigoyen (1975). These authors have studied several cross-sections at all the Province and found faults which affected the Miocene formations and even the Epiparaniana section. It may be observed in Fig. 2 that there is a great system of faults in all the basins of the Province.

Water conductivity greatly increases below $28 \mathrm{~m}$ at some places and at $60 \mathrm{~m}$ depth at other places, which represents a limitation to the available water for irrigation.

Higher resistivity (possibly calcareous nodules) and the subjacent salty stratum (Puelches and Green Miocene Formations) at different depths at both sides of the Pergamino rivulet show evidence of lateral discontinuities caused by the structural controls previously mentioned.

\section{METHODOLOGY AMT soundings}

As it is known, electromagnetic methods lead to the knowledge of the electrical resistivity distribution in the earth. The geomagnetic variations primarily, produced by distant thunderstorms, together with the induced electrical field in the earth, are measured. Lowfrequency signals penetrate farther into the subsurface and yield information on greater depths, due to the skin effect, whereas high-frequency signals pertain to shallower depths. As electrical resistivity varies with sediment type and water content, these methods can be used to infer lithology and aquifer properties.

Twelve Audio-magnetotelluric (AMT) soundings were performed at the study area (Fig. 3) at sites coinciding with previous VES (Sainato et al., 1998; 2000). A natural source equipment was used in the range of 10 to $2500 \mathrm{~Hz}\left(0.1\right.$ to $\left.10^{-4} \mathrm{sec}\right)$. Electrical signals were measured with a $50 \mathrm{~m}$ telluric dipole arranged on the land surface at a NS or EW direction, while the magnetic field was simultaneously measured 

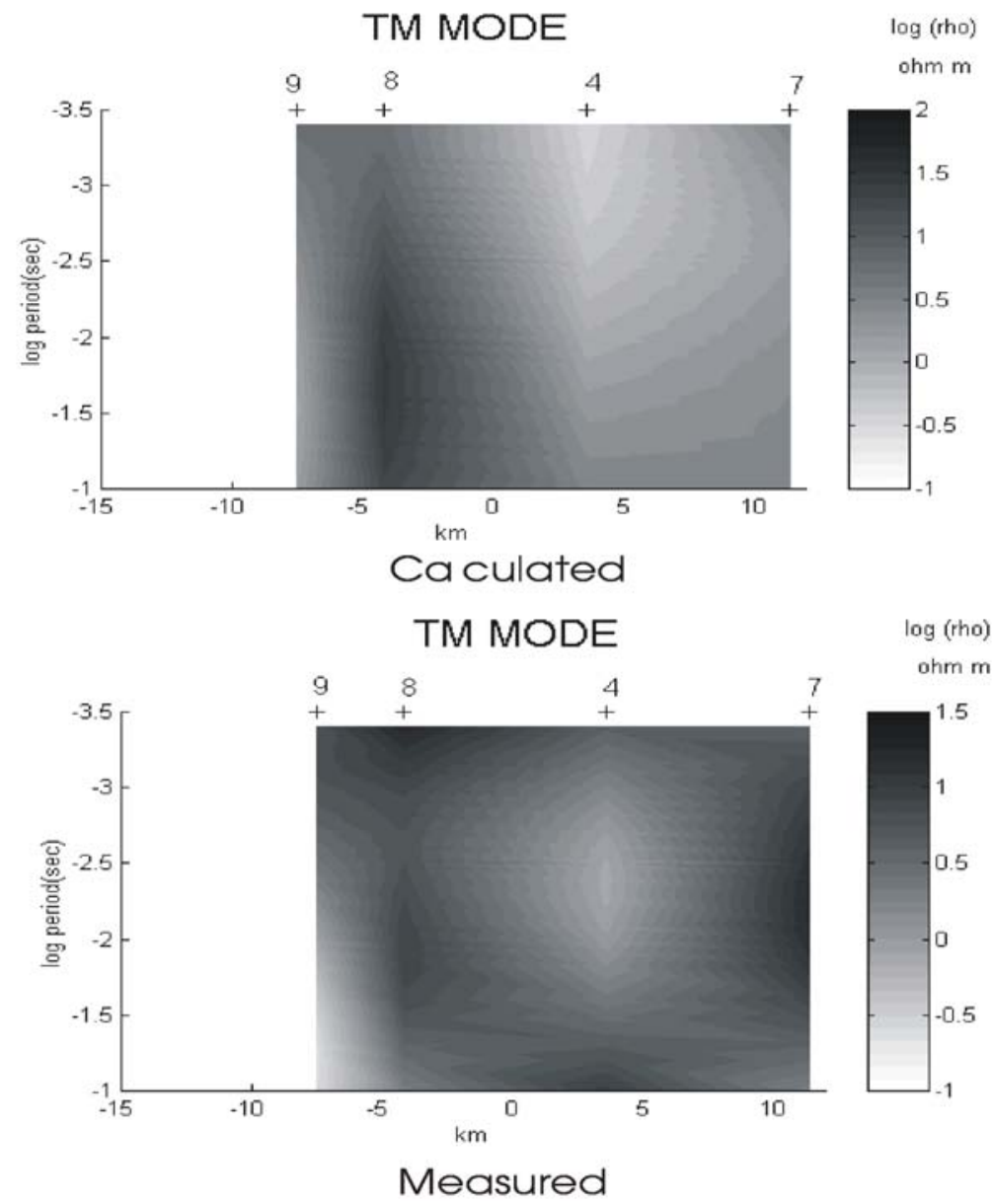

Figure 8 - Calculated and measured pseudosections of apparent resistivity for TM mode for profile BB'.

Figura 8 - Pseudo-seção de resistividade aparente calculada e medida para modo TM, para o perfil BB'

with an induction coil oriented at right angle to the telluric line (EW or NS, respectively). Measured at different frequencies, field amplitudes are digitized and used to calculate apparent resistivities.

The rho plus algorithm of Parker \& Booker (1996) was used to determine the offset in gain at certain bands at some sites in order to predict the apparent resistivities from values outside these bands. Downward bias, produced by static shifts was repaired comparing the experimental AMT curves, in the range of shorter periods, with the AMT theoretical response produced by the previous VES models. In case where a shift in the experimental AMT curves were observed they were corrected by the appropriate factor.

Strike direction may be considered nearly EW along the Pergamino rivulet, taking into account the geological environment of Fig. 2 and previous VES results which have shown different resistivity distribution with depth at both sides of the rivulet. Then, the TE mode corresponds to the EW telluric component $\left(\mathrm{r}_{\mathrm{yx}}\right)$ and the TM mode $\left(\mathrm{r}_{\mathrm{xy}}\right)$ to the NS electrical field. Even if the apparent resistivity curves for the two modes were very similar at some sites, a 2D inversion was carried out using the Smith \& Booker ( 1991 ) program.

\section{Geochemical analysis}

There are no wells with geologic logs in the study area except at the city or towns, where two of them (M.Ocampo and M. Alfonzo) are located at a few kilometers from sites AMT12 and AMT9 respectively and their lithological descriptions (Fig. 4) were compared with AMT results.

Fourteen water samples were collected in March 1998, from wells distributed over the study area, reaching the Pampeano aquifer, for rural use and irrigation (see Fig. 3). In general, water samples were taken below a $25 \mathrm{~m}$ depth. Samples were refrigerated at $4^{\circ} \mathrm{C}$ and analyzed for contents of: sodium, potassium, calcium, magnesium, chlorides, carbonates, bicarbonates, 

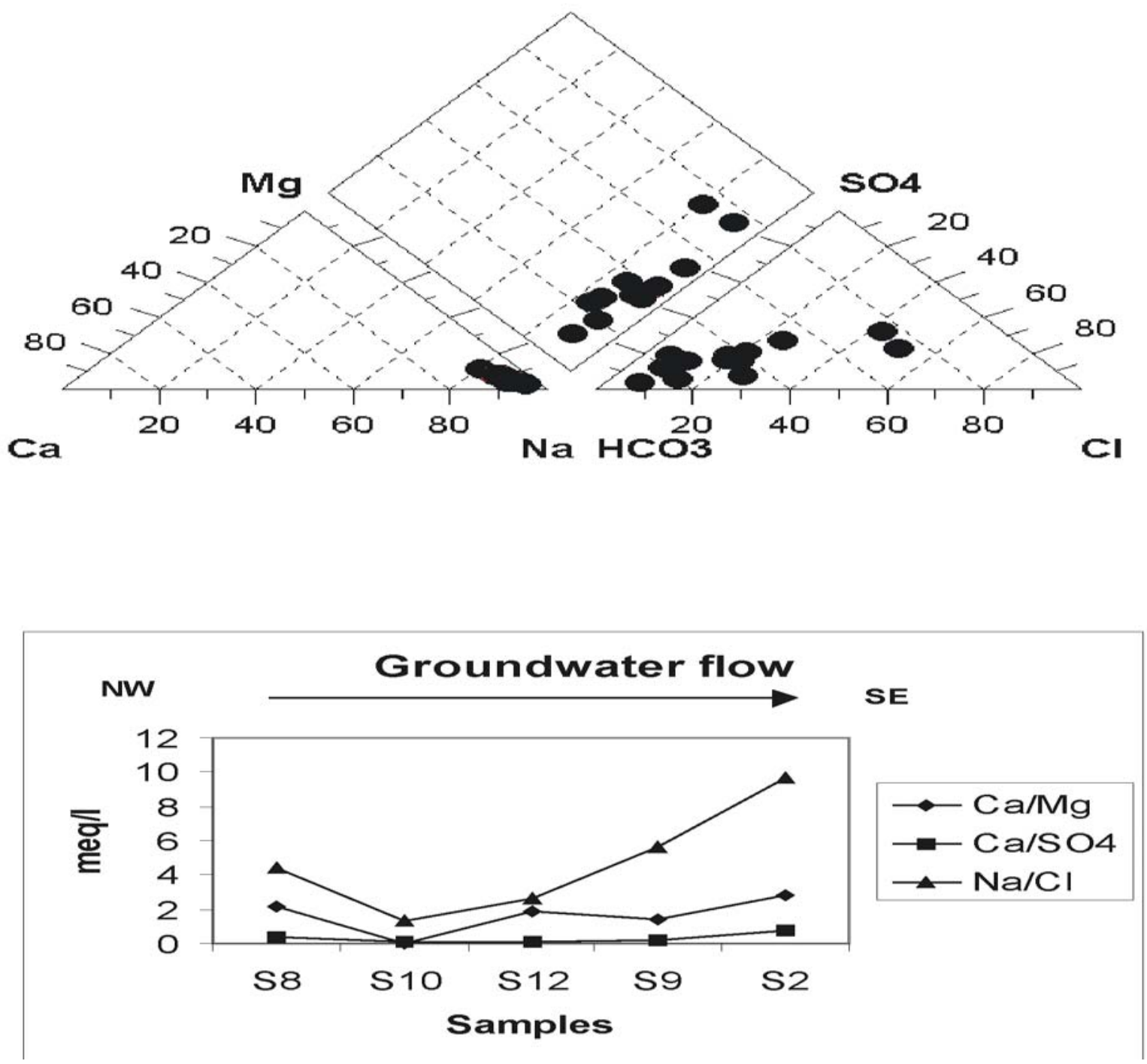

Figure 9a - Piper diagram from water samples obtained at wells distributed at the study area of Fig. 3 b. Geochemical relationships in meq/l.

Figura 9a - Diagrama de Piper das amostras obtidas de água dos poços distribuidos na área de estudo da Fig.3b. Relações geoquímicas em meq/l.

sulfates, electrical conductivity, $\mathrm{pH}$, and Total Dissolved Solids (TDS) (Tab. I). Water was then characterized using a Piper diagram.

The chemical evolution along the regional direction of groundwater flow (parallel to the Pergamino rivulet) was defined with an hydrochemical profile, taking into account the main geochemical relationships: $\mathrm{Ca} / \mathrm{Mg}$, $\mathrm{Ca} / \mathrm{SO}_{4}$ and $\mathrm{Na} / \mathrm{Cl}$.

\section{AMT RESULTS}

Apparent resistivity curves after applying static shift corrections and Rhoplus program are shown in Fig. 5.

The 2D inversion of MT apparent resistivity was carried out taking to account an EW strike in two profiles crossing the Pergamino rivulet (AA' and BB') shown in Fig. 3. TE and TM mode were inverted for profile AA' whereas TM mode was used for profile BB'due to the absence of TE data for site AMT9. Fig. $6 \mathrm{a}$ and $6 \mathrm{~b}$ show the final model after inversion and the residuals for profiles AA' and BB', respectively. The calculated and measured pseudosections are shown in Figs. 7 and 8 for profile AA' and BB', respectively.

In profile $\mathrm{AA}^{\prime}$, it may be observed a layer with resistivities of $30 \mathrm{ohm}$ m approximately from AMT1 to the north, being its base between 50 and $70 \mathrm{~m}$ depth. The resistivity increases towards the south reaching values greater than $100 \mathrm{ohm} \mathrm{m}$ and its base is at $25 \mathrm{~m}$ depth. From M.Ocampo well (Fig. 4), this layer must 



Figure10 - Distribution of water electrical conductivity (a) and water sodium content (b) from samples using kriging interpolation.

Figura 10 - Distribuição da condutividade elétrica (a) e o conteúdo de sódio (b) da água das amostras usando interpolação por krigagem. 


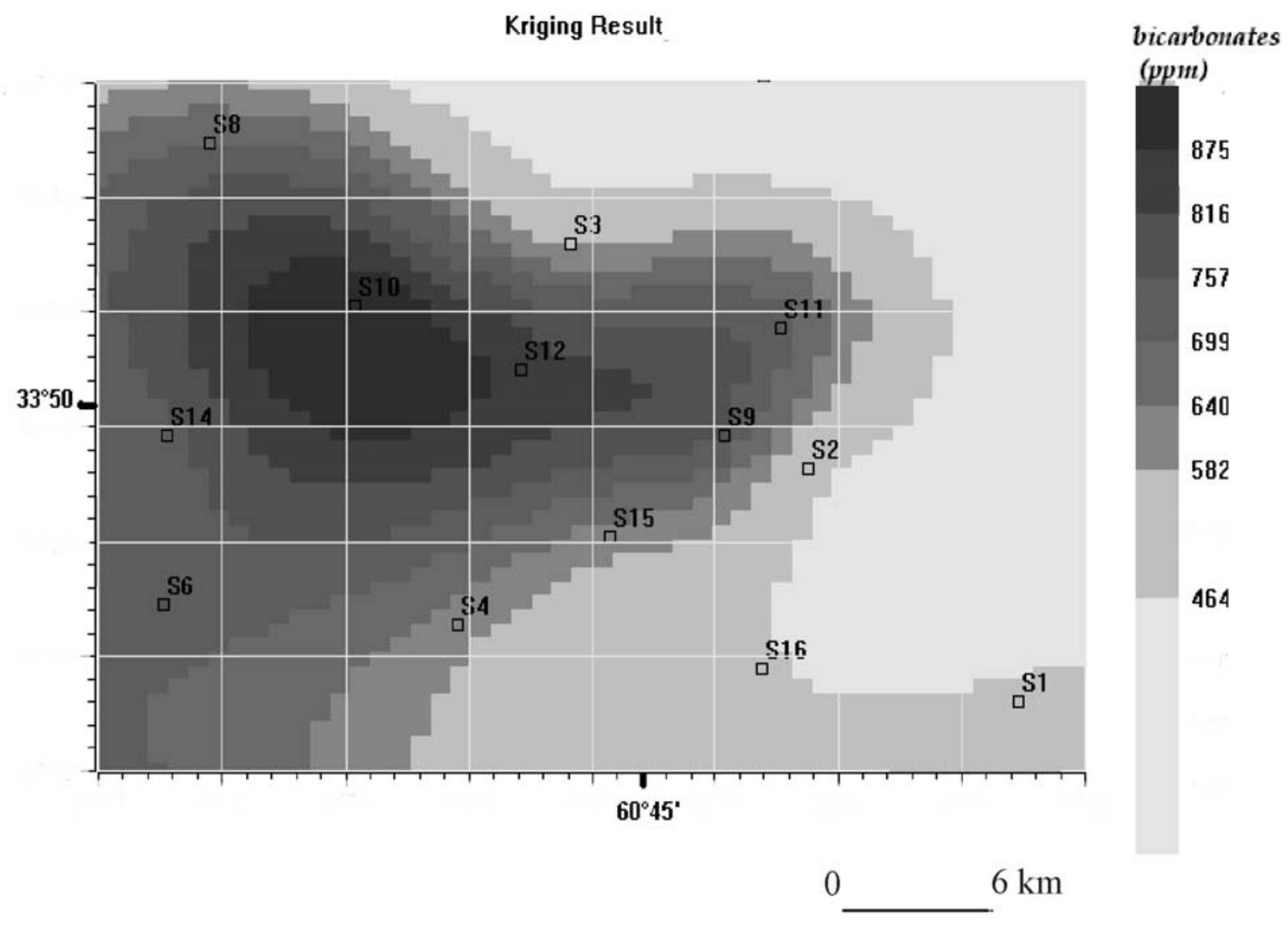

Figure 11 - Distribution of water bicarbonate content from samples using kriging interpolation.

Figura 11 - Distribuição do conteúdo de bicarbonato da água das amostras usando interpolação por krigagem.

be composed by clayey-silty sediments with calcareous crust. This layer may be associated with the Pampeano aquifer which has in its upper section free groundwater and in the lower section there are up to five productive levels, partially confined when clayey layers with aquitard behaviour are found at the bottom. This aquitard separates the Pampeano and the lower Puelches sands (Fresina et al., 1993). The presence of calcareous intercalation (Sala \& Rojo, 1994) as nodules or continuous plates, evidenced in Fig. 4, may increase the resistivity of the layers. In general, from previous geological information and well data there are no great lithological variations in the Pampeano aquifer in all the zone (Clayey-silty sediments) so it may be supposed that changes in resistivity are strongly affected by water quality. Conductivity AMT results coincide approximately with the ones obtained from geochemical analysis of water samples (Tab. 1).

It may also be observed that S16 and S2 water samples have greater conductivities than S9, S11 and the value of $1352 \mathrm{mS} / \mathrm{cm}$ (resistivity about $7 \mathrm{~W} \mathrm{~m}$ ) from well M. Ocampo, which agree with the increase of resistivity towards the southern part of the profile (AMT resistivities between 3 and $10 \mathrm{~W} \mathrm{~m}$ ). Below, there is a conductive layer associated with the Puelches and Green Miocene Formation which have a great content of salts. The lateral variations in electrical resistivities at both sides of the Pergamino rivulet were also recognized in previous results (Sainato et al., 1998; 2000). This may be an evidence of structural controls (Irigoyen, 1975) which also modify the direction of the Pergamino rivulet course. The fluvial network may be controlled by the morphology, the structure or both of them. Cross-sections at different places in the Province have shown fractures which have caused a stratigraphic throw in the Red and Green Miocene formations. There have been reactivations of some faults which have affected shallower and more recent formations (Irigoyen, 1975).

In profile $\mathrm{BB}^{\prime}$, a conductive layer which reaches almost $40 \mathrm{~m}$ depth increasing its conductivity from AMT8 to the north is the Pampeano aquifer, with greater values (AMT resistivities between 1 and $3 \mathrm{Wm}$ ) than the AA' profile. M. Alfonzo well shows thick silt 
sediments, and water conductivity is $1300 \mathrm{mS} / \mathrm{cm}$ (resistivity of $7.7 \mathrm{Wm}$ ) very close to the resistivity at site AMT9 $(6 \mathrm{Wm})$. Water conductivity from wells S14, $\mathrm{S} 10$ and S13 is also higher than most of the wells located near profile AA'. Profile BB' is located at a swamp zone, a recharge area of groundwater flow (Sainato et al., 1998; 2000) mainly by infiltration from precipitation events. At this zone, Natracuoll soils with very low permeability and deficiency in drainage have a large time of water residence, which helps the incorporation of salts to the shallower aquifers. A light increase of resistivity with depth may be observed up to $100 \mathrm{~m}$ at the north of the profile and deeply at the south. Below, the conductivity increases probably showing the salty Puelches and Green Miocene Formations.

\section{GEOCHEMICAL RESULTS}

In Fig. 9a, groundwater is characterized using a Piper diagram, resulting in $79 \%$ of the samples of bicarbonate sodium type and $21 \%$ with no anion dominating.

The hydrochemical evolution along a profile parallel to the Pergamino rivulet (Fig. 9b) shows the relations $\mathrm{Ca} / \mathrm{Mg}, \mathrm{Ca} / \mathrm{SO}_{4}$ and $\mathrm{Na} / \mathrm{Cl}$, from $\mathrm{NW}$ to $\mathrm{SE}$ coinciding with regional groundwater flow observed in previous studies (Sainato et al., 1998; 2000) . There is a slight tendency in $\mathrm{Na} / \mathrm{Cl}$ in the last sample.

The distribution of water electrical conductivity and sodium content at the studied zone was obtained by means of kriging interpolation (Trangmar et al., 1985) from water samples. These results are shown in Figs. $10 \mathrm{a}$ and $10 \mathrm{~b}$ respectively, together with the location of the wells.

An increase of conductivity and sodium content at the swamp zone is observed characterized by less permeable soil with deficiency in drainage (Natracuolls soil) and a slight slope of phreatic level. This is in agreement with the higher values of conductivity obtained from AMT results at profile $\mathrm{BB}^{\prime}$ than the $\mathrm{AA}^{\prime}$, for the Pampeano aquifer.

As it has been mentioned before, at this zone, water moves more slowly with a larger time of contact with the subsoil material, dissolving salts. Linear correlation between electrical conductivity and sodium content was found to be very significant $\left(\mathrm{r}^{2}=0.97\right)$. The results of kriging for bicarbonates are shown in Fig. 11 with greater concentration in the swamp zone. Correlation between electrical conductivity and bicarbonates was also significant $\left(r^{2}=0.79\right)$.

\section{CONCLUSIONS}

The upper hydrogeological sections at the Pergamino basin were characterized through AMT soundings more accurately than in previous studies.

The Epiparaniana section, including the Puelches and the Pampeano Formations, was sensed in two profiles crossing the Pergamino rivulet bed, one in the west of the city and the other one in the recharge swamp zone.

The AMT results were compared with well data, taking into account the geological and hydrogeological background. Resistivity from well data exploiting the Pampeano aquifer is close to the AMT results.

The Pampeano aquifer has been identified in the first profile with a base at $50-70 \mathrm{~m}$ depth at the left margin of the rivulet and at $25 \mathrm{~m}$ depth with higher resistivity at the right margin. This increase in resistivity agrees with the better water quality found at the wells towards the southern part of the profile. Below, the bad water quality aquifers of the Puelches and Green Miocene Formations have been associated with a very highly conductive layer which deepens to the north.

At the second profile at the swamp zone, the Pampeano aquifer has lower resistivities than the previous profile with a base at $40 \mathrm{~m}$ depth approximately. Water conductivity from wells also showed greater values for this zone.

The areal distribution of conductivity and sodium content obtained from well data in all the basin shows maximum values at this swamp zone. Natracuolls soils with very low permeability and deficiency in drainage, together with a soft topographic slope produce a greater time of residence and water moves more slowly with a larger time of contact with the subsoil material, dissolving salts which may affect the shallower aquifers.

Below, an increase in conductivity shows the presence of the salty Puelches and Green Miocene Formations.

Lateral variations in electrical resistivities found at both margins of the Pergamino rivulet which were also recognized in previous results may be an evidence of faults which also modify the direction of the Pergamino rivulet course. Previous studies have recognized, in geological cross-sections at different places in the Province, the presence of fractures which have caused a stratigraphic throw in the Red and Green Miocene Formations, and probably reactivations of these faults affecting even the shallower and more recent Formations . 
The Pampeano aquifer has bicarbonate sodium water. Hydrochemical evolution along the course of Pergamino rivulet shows a slight increase in $\mathrm{Ca} / \mathrm{Mg}$, $\mathrm{Ca} / \mathrm{SO}_{4}$ and $\mathrm{Na} / \mathrm{Cl}$ relationships in the direction of regional groundwater flow, to the $\mathrm{SE}$.

\section{ACKNOWLEDGEMENTS}

The authors would like to thank Mrs. Amalia González for helping with the illustrations. This work was financially supported by the University of Buenos Aires.

\section{REFERENCES}

FERNÁNDEZ GARRASINO, C. \& URBA, A. - 1999 Estructura del tope de la Formación Serra Geral (Neojurásico-Eocretácico) en la Mesopotamia argentina y adyacencias. Actas del XIV Congreso Geológico Argentino. Salta. Argentina, 185-188.

FRESINA, M., LOPEZ, A.C. \& DE LA TORRE, G.R. - 1993 - Características hidrodinámicas de los niveles productivos de agua potable para la ciudad de Pergamino. V Jornadas Pampeanas de Ciencias Naturales. La Pampa. Argentina., p.19.

IRIGOYEN, M. - 1975 - Geología del subsuelo y plataforma continental. Relatorio de la Pcia. De Bs. As., VI Congreso Geológico Argentino, B. Blanca, 139-169.

PARKER, R. \& BOOKER, J. - 1996 - Optimal onedimensional inversion and bounding of magnetotelluric apparent resistivity and phase measurements, Phys. Earth.Planet. Int., 98: 269-282.

SAINATO, C., POMPOSIELLO,M., GALINDO, G. \& MALLEVILLE, H. -1998- AMT and geoelectrical soundings for groundwater prospecting at Pergamino basin (Buenos Aires Province, Argentina). 14 ${ }^{\text {th }}$ Workshop on Electromagnetic Induction in the Earth, Sinaia, Rumania.

SAINATO C., LOSINNO B., LANDINI A., GALINDO G. \& POMPOSIELLO M.C. - 2000 - Prospección de los acuíferos subterráneos de la zona de PergaminoArrecifes, Provincia de Buenos Aires, mediante sondeos geoelectricos. Actas del XVII Congreso Argentino de la Asociación de Ciencia del Suelo, Mar del Plata. Argentina.,CD-ROM, Com. IV-51.

SALA, J. M. - 1969 - El Agua subterránea en el NE de la Prov. de Bs. AS. Argentina. In: Proceedings of the Reunión Geológica del Agua subterránea. CIC. La Plata. Prov. de Bs. As. Argentina, 25-49.

SALA, J. M. - 1975 - Recursos hídricos. Relatorio de la Pcia. De Bs. As. , VI Congreso Geológico Argentino, B. Blanca, 169-193.

SALA, J. M., GONZÁLEZ, N. \& KRUSE, E. - 1983 Generalización hidrológica de la Prov. de Bs. As. In: (Ed.) UNESCO. Coloquio internacional sobre hidrología de grandes llanuras, 973-1009.

SALA, J. \& ROJO, A. - 1994 - Pasado, presente y futuro de la hidrología subterránea en la Pcia de Buenos Aires, Rep. Arg. In: Bocanegra, E. \& Rapaccini, A. (Eds.), Temas actuales de la hidrología subterránea. CFI. UNMP, 209-224.

SANTA CRUZ, J. \& SILVA BUSSO, A. - 1995 Disponibilidad del agua subterránea para riego complementario en las Pcias. de Bs. As., E. Ríos, Córdoba y Santa Fe. Report. Programa de Servicios Agrícolas provinciales. Secretaría de Agricultura, Ganadería y Pesca (Argentina), 16-27.

SMITH, J. T. \& BOOKER, J. R. -1991- Rapid inversion of two-and three-dimensional magnetotelluric data. Journal of Geophysical Research, 96 (B3) : 3905-3922.

TRANGMAR, B.B., YOST, R.S. \& UEHARA, G. -1985 -. Applications of geostatistics to spatial studies of soil properties. Advances in Agronomy, 38: 45 -94.

URIEN, C. M. \& ZAMBRANO, J. J. - 1996-Estructura del margen continental. XIII Congreso Geológico Argentino y III Congreso de exploración de Hidrocarburos. Bs. As. Geología y recursos naturales de la Plataforma Continental Argentina. Ramos V. \& Turic M. A. (Eds). Relatorio, 3: $29-65$.

USUNOFF, E. J. - 1994 - Técnicas de estudios en llanuras. In: Bocanegra, E. \& Rapaccini, A. (Eds.). Temas actuales de la hidrología subterránea. CFI. UNMP, Argentina, 103-117. 